DOI: 10.17707/AgricultForest.62.4.12

\author{
Anna TRAKOVICKÁ, Nina MORAVČÍKOVÁ, \\ Alica NAVRÁTILOVÁ, Radovan KASARDA ${ }^{I}$
}

\title{
CARCASS AND MEAT QUALITY IN RELATION TO THE POLYMORPHISM IN PORCINE MYF4 GENE
}

\begin{abstract}
SUMMARY
The aim of this study was to analyse the associations between polymorphism in porcine myogenin gene (MYF4) and economically important traits in relation to the carcass and meat quality of pigs. The genomic DNA samples were taken from in total 180 crossbreeds (Large White $\mathrm{x}$ Landrace). The detection of polymorphism in MYF4 gene were performed in order to evaluate its effect on back fat thickness, proportion of valuable meat parts, MLT area and proportion of thigh. The genotyping of analysed individuals was carried out by means PCR-RFLP method and restriction endonuclease MspI. The allele frequencies were as follows: A 0.75 and B 0.25 . A prevalence of AA genotype (59\%) compared to $\mathrm{AB}(33 \%)$ and $\mathrm{BB}$ genotypes $(8 \%)$ were detected in analysed crossbreed population. The observed average value of heterozygosity $(0.33)$ and positive value of the Wright's $F_{I S}$ index (0.12) similarly reflected the higher proportion of homozygous genotype in populations. The effect of MYF4 gene polymorphism on selected phenotypic traits has been tested using one-way ANOVA procedure. The statistical analysis showed only non-significant results. Due to the polygenic character of selected phenotypic traits the involvement of other candidate genes and increase of sample size could clarify the role of $M Y F 4$ gene in porcine carcass and meat quality regulation. The study, which is based on molecular variability of livestock genetic resources, is necessary for the genetic improvement and understanding of relations between markers and trait of interest.
\end{abstract}

Keywords: genetic variability, myogenin gene, meat quality, SNP, pig.

\section{INTRODUCTION}

The pig breeding plays currently a key role in meat production, and the high consumption of pork corresponds to this. The high efficiency of pig breeding is absolutely necessary for competitiveness under today's difficult economic conditions (Weisz et al., 2011). One of goals of animal genetics is to locate and identify loci that are responsible for economical important traits such

\footnotetext{
${ }^{1}$ Anna Trakovická, Nina Moravčíková, (corresponding author: nina.moravcikova@uniag.sk), , Alica Navrátilová, Radovan Kasarda, Department of Animal Genetics and Breeding biology, Slovak University of Agriculture in Nitra, Nitra, SLOVAKIA.

Paper presented at the $7^{\text {th }}$ International Scientific Agricultural Symposium "AGROSYM 2016".

Notes: The authors declare that they have no conflicts of interest. Authorship Form signed online.
} 
as meat performance, reproduction, and product qualities which are the most significant factors for pork production efficiency (Bulla et al., 2007).

Variation in meat quality is likely to be caused by differences in many genetic and non-genetic (environmental) factors, which interact together and determine the course of metabolic processes in muscle tissue and in the postmortem conversion of muscle into meat (Kapelañski et al., 2005). Intensive selection for lean growth in pigs may have caused a considerable genetic change in fibre type composition, which resulted in a higher proportion of glycolytic fibres and in an increase in fibre diameter in domestic pigs compared to native breeds. Changes in fibre type ratios affect metabolic properties of a muscle and thereby meat quality (Kłosowska et al., 2004).

Histochemical and biochemical muscle fibre properties are the factors that influence the quantitative and qualitative characteristics of pork meat (Stupka et al., 2014). Muscle fibre formation takes place during embryonic development in mammals and is controlled by the $M y o D$ gene family, which consists of four genes, MyoDl (MYF3), myogenin (MYOG or MYF4), MYF5 and MYF6 (MRF4) (Horák et al., 2004; Zhang et al., 2007; Ujan et al., 2011). The expression of the MYF5 and MYOD1 (MYF3) genes plays a fundamental role during myoblast proliferation, while the expression of the MYOG (MYF4) and the MYF6 (MRF4) genes is linked to the differentiation and maturation of myofibres (Stupka et al., 2012). The myogenin (MYF4) gene, which controls the start of myoblast fusion and myofibres formation, was identified on the $9^{\text {th }}$ autosome, in the $9 \mathrm{q} 2.1-2.6$ area (Soumillion et al., 1997; Ernst et al. 1998). The myogenin is a transcription factor specific to skeletal muscle and fulfils a key function in muscle differentiation by controlling the onset of myoblast fusion and the establishment of myofibres. Genetic variation in the MYF4 gene can be associated with differences in myoblast and myofibril numbers (Weisz et al., 2011). Ernst et al. (1993) and Soumillion et al. (1997) detected using endonuclease MspI gene three polymorphic sites in the MYF4, in the promoter region, the second intron and the 3 ' side of the gene.

The aim of this study was to analyse the effect of polymorphism in porcine MYF4 gene on economically important traits in relation to the carcass and meat quality in population of Large White $\mathrm{x}$ Landrace crossbreeds.

\section{MATERIAL AND METHODS}

The biological samples were collected in 2014 from in total of 180 crossbreeds of Large White x Landrace (86 boars and 94 sows) from the Experimental Centre of Farm Animals (Department of Animal Husbandry, Slovak University of Agriculture in Nitra, Slovakia). Each of selected individuals included in present study have been farmed in the same conditions and fed with standard feed mixtures.

To extract of genomic DNA from blood samples the protocol according to Miller et al. (1988) has been used. Subsequently, the concentration and purity of genomic DNA were analysed based on the spectrophotometry measurements by 
the optical density at wave length of $260 \mathrm{~nm}$. The polymorphism in MYF4 gene was analysed according to Soumillion et al. (1997) using restriction endonuclease $M s p I$. The products of PCR reaction and restriction fragments have been separated and visualised using horizontal electrophoresis in $2 \%$ agarose gels (130 V for $50 \mathrm{~min}$ ) and stained with day GelRed.

The genotypic structure of population and allele frequencies have been determined using Genalex version 6.1 (Peakall and Smouse, 2012). The HardyWeinberg equilibrium in population was tested based on the significance between observed and expected genotype frequencies using Chi-square test. The diversity indices including observed $\left(\mathrm{H}_{\mathrm{o}}\right)$ and expected heterozygosity $\left(\mathrm{H}_{\mathrm{e}}\right)$, effective allele numbers $\left(\mathrm{N}_{\mathrm{e}}\right)$, polymorphic information content (PIC), and $\mathrm{F}_{\mathrm{IS}}$ index was calculated using Genalex version 6.1 (Peakall and Smouse, 2012).

The effect of MYF4 has been studied in relation to the back fat thickness (BFT), lean meat percentage (LM), thigh percentage (TP) and MLT area. Each of these carcass and meat quality indicators was measured according to Slovak standard technical norm (STN 466164). The associations between locus in MYF4 gene and selected production parameters have been analysed using One-way ANOVA procedure incorporated in SAS software environment (SAS Institute Inc., 2009).

\section{RESULTS AND DISCUSSION}

In analysed population of Large White $\mathrm{x}$ Landrace crossbreeds the prevalence of homozygous AA genotype was found (59\%), whereas the $\mathrm{AB}$ heterozygotes reached the level of 33\%. The lowest proportion was observed for BB homozygotes (8\%). The A allele was more frequent (0.75) than B allele (0.25). The higher proportion of homozygotes across all evaluated individuals was reflected in the decrease of $\mathrm{H}_{\mathrm{o}}$ and $\mathrm{H}_{\mathrm{e}}$ heterozygosities (0.33 and 0.39). The differences between observed and expected genotype frequencies have been only non-significant $(\mathrm{P}<0.05)$ that indicated the Hardy-Weinberg equilibrium in population. The value of $\mathrm{N}_{\mathrm{e}}$ (1.59) signalised unbalanced alleles activity and observed value of polymorphic information content (0.38) showed medium level of polymorphism according to Botstein et al. (1980). The positive value of $\mathrm{F}_{\mathrm{IS}}$ index (0.12) and also relative high value of observed homozygosity (0.67) indicated the deficiency of heterozygous animals compared to the HardyWeinberg expectations. The value of $\mathrm{F}_{\mathrm{IS}}$ index, which is also considered as molecular equivalent of individual inbreeding coefficient with respect to the population, reflected in analysed population the increase of homozygosity resulting probably from the higher animal's relatedness and signalized the risk of inbreeding increase in the future generations.

The effect of MYF4 gene polymorphism has been analysed in association to four indicators reflected carcass and quality of pork meat: back fat thickness, lean meat percentage, thigh percentage and MLT area. Table 1 shows the observed average values of analysed traits in relation to the MYF4 genotypes. Contrary to the expectations resulting from previously published studies (Verner 
et al., 2007; Civaňova and Knoll, 2007; Stupka et al., 2012) all of the MYF4 genotypes showed only non-significant $(\mathrm{P}<0.05)$ impact on selected production traits.

Table 1. Average values of measured traits in relation to MYF4 polymorphism genotypes

\begin{tabular}{|c|c|c|c|c|c|c|c|c|c|}
\hline \multirow{3}{*}{ Genotypes } & \multirow{2}{*}{$\mathrm{N}$} & \multicolumn{7}{|c|}{ Traits (in average) } \\
\cline { 3 - 10 } & & BFT (mm) & P & LP (\%) & P & $\begin{array}{c}\text { MLT } \\
\text { area }\left(\mathrm{cm}^{2}\right)\end{array}$ & P & TP (\%) & P \\
\hline AA & 106 & $17.30 \pm 3.51$ & ns & $55.35 \pm 1.90$ & ns & $43.76 \pm 3.79$ & ns & $22.62 \pm 1.24$ & ns \\
\hline AB & 59 & $17.40 \pm 3.53$ & ns & $55.08 \pm 1.77$ & ns & $44.56 \pm 4.85$ & ns & $22.62 \pm 1.28$ & ns \\
\hline BB & 15 & $16.71 \pm 3.11$ & ns & $55.56 \pm 2.35$ & ns & $43.53 \pm 4.03$ & ns & $22.82 \pm 1.42$ & ns \\
\hline
\end{tabular}

ns - not significant, BFT - back fat thickness, LP - lean meat percentage, MLT area - area of musculus longisimus thoracis, TP - thigh percentage (\%)

The associations of MYOD genes family with pork quality has been previously investigated in various pig populations by several studies (Soumillion et al., 1997; Kapelañski et al., 2005; Cinar et al., 2012; Stupka et al., 2014). The $M y o D$ genes were tested as candidate genes with an expected, significant effect principally on the muscle deposition (Kłosowska et al., 2004). The genetic variation in the MYF4 gene has been associated mainly with differences in myoblast and myofibre numbers (Soumillion et al., 1997; Kim et al., 2009). Te pass et al. (2004) revealed that the level of MYF4 gene mRNA expression is localized mainly in red muscles in animals at slaughter and is associated with muscle fibre type. Gerześ et al. (2010) and Stupka et al. (2014) reported significant effect of MYF4 polymorphism on the number of muscle fibres per area unit in pigs. Some authors also showed that the MYF4 gene had also a tendency to regulate backfat thickness (Civaňova and Knoll, 2007). The animals with AA genotype were associated with increase birth weight, growth rate and content of lean meat (Te Pass et al., 1999). In the Czech Large White population was found the significant association between MYF4 gene polymorphism and back fat thickness (Verner et al., 2007). Based on this and due to the polygenic character of selected phenotypic traits the involvement of other candidte genes mainly from $M Y O D$ family and increase of sample size is in the future studies needed in order to clarify the role of MYF4 gene in porcine carcass and meat quality regulation.

\section{CONCLUSIONS}

In analysed population of Large White $\mathrm{x}$ Landrace crossbreeds the prevalence of homozygous AA genotype was found, whereas the lowest proportion was observed for BB homozygotes. The lower proportion of heterozygotes within population was reflected in the decrease of genetic variability represented by FIS index and heterozygosity. Moreover, the FIS index as molecular equivalent of inbreeding coefficient signalized for the analysed 
population the risk of animal's relatedness increase in the next generations. In the contrary to the expectations resulted from the previously reported studies the MYF4 genotypes showed only non-significant $(\mathrm{P}<0.05)$ impact on all of the analysed production traits. In the future, the involvement of other candidate genes and increase of sample size could clarify the role of MYF4 gene in porcine carcass and meat quality regulation.

\section{ACKNOWLEDGEMENT}

This work has been supported by the Slovak Research and Development Agency (Contract No. APVV-14-0054 and No. APVV-0636-11).

\section{REFERENCES}

Botstein, D., White, R. L., Skolnick, M., Davis, R. W. (1980). Construction of a genetic linkage map in man using restriction fragment length polymorphisms, American Journal of Human Genetics, 32, 314 - 331.

Bulla, J., Omelka, R., Jasek, S., Čurlej, J., Bencsik, J., Filistowicz, A. (2007). Genetics and molecular biology and pig meat quality improvement, Lucrări ştiinţifice Zootehnie şi Biotehnologii, 40(1).

Cinar, M. U., Fan, H. T. (2012). The mRNA expression pattern of skeletal muscle regulatory factors in divergent phenotype swine breeds, Kafkas Üniversitesi Veteriner Fakültesi Dergisi, 18(4), 85 - 690.

Civaňova, K., Knoll, A. (2007). SNaPshot minisequencing and a panel of candidate genes for complex routine testing of meat performance traits in pigs, Animal Biotechnology, 18, 109 - 115.

Ernst, C. W., Mendez, E. A., Robic, A., Rothschild, M. F. (1998). Rapid communication: Myogenin (MYOG) physically maps to porcine chromosome 9q2.1-q2.6, Journal of Animal Science, 76, 328.

Ernst, C. W., Vaske, D. A., Larson, R. G., Rothschild, M. F. (1993). MspI restriction fragment length polymorphism at the swine MYOG locus, Journal of Animal Science, 71, 3479.

Grześ, B., Pospiech, E., Koćwin-Podsiadla, M., Łyczyński, A., Krzecio, E., Mikolajczak, B., Iwańska, E. (2010). Relationships between the polymorphism of myosin heavy chains and selected meat quality traits of pigs with different susceptibility to stress, Archiv Tierzucht, 53, 65 - 72.

Horák, P., Urban, T., Dvořák, J. (2004). Genetic variability of the CRC and MYF4 genes in genetic resource, Přšstice Black-Pied pig, Archiv Tierzucht, 47, 3, 231 - 238.

Kapelañski, W., Grajewska, S., Kuryl, J., Bocian, M., Wyszynska-Koko, J., Urbanski, P. (2005). Polymorphism in coding and non-coding regions of the MyoD gene family and meat quality in pigs, Folia Biologica Krakow, 53, 45 - 49.

Kim, J. M., Choi, B. D., Kim, B. C., Park S. S., Hong K. C. (2009). Associations of the variation in the porcine myogenin gene with muscle fibre characteristics, lean meat production and meat quality traits, Journal of Animal Breeding and Genetics, 126, 134 - 141.

Klosowska, D., Kuryl, J., Elminowska-Wenda, G., Kapelanski, W., Walasik, K., Pierzchala, M., Cieslak, D., Bogucka, J. (2004). A relationship between the PCRRFLP polymorphism in porcine MYOG, MYOD1 and MYF5 genes and microstructural characteristics of $\mathrm{m}$. longissimus lumborum in Pietrain x (Polish 
Large White x Polish Landrace) crosses, Czech Journal of Animal Science, 49, 99 $-107$.

Miller, S. A., Dykes, D. D., Polesky, F. H. (1988). A simple salting out procedure for extractin DNA from human nucleated cells, Nucleic Acids Research, 16, 1215.

Peakall, R., Smouse, P. E. (2012). GenAlEx 6.5: genetic analysis in Excel. Population genetic software for teaching and research-an update, Bioinformatics, 28, 2537 2539.

SAS Institute Inc. (2009). Administering SAS® Enterprise Guide® 4.2. Cary, NC: SAS Institute Inc.

Soumillion, A., Erkens, J. H. F., Lenstra, J. A., Rettenberger, G., te Pas, M. F. W. (1997). Genetic variation in the porcine myogenin gene locus, Mammal Genome, 8, 564 568.

Stupka, R., Citek, J., Sprysl, M., Okrouhla, M., Brzobohaty, L. (2012). The impact of MYOG, MYF6 and MYOD1 genes on meat quality traits in crossbred pigs, African Journal of Biotechnology, 11(88), 15405 - 15409.

Stupka, R., Č́itek, J., Šprysl, M., Okrouhlá, M., Brzobohatý, L., Stádník, L., Zita, L. (2014). Histological characteristics of the musculus longissimus lumborum et thoracis muscle fibres in pigs in relation to selected RYR1, MYOG, MYOD1 and MYF6 genotypes, Acta veterinaria Brno, 83: 233 - 237.

Te Pas, M. F. W., Everts, M. E., Haagsman, H. P. (2004). Muscle development of livestock animals: physiology, genetics and meat quality, CABI Publishing, Wallingford, Oxfordshire, UK.

Te Pas, M. F. W., Soumillion, A., Harders, F. J., Verburg, F. J., Van Der Bosch, T. J., Galesloot, P., Meuwissen, T. H. E. (1999). Influences of Myogenin Genotypes on Birth Weight, Growth Rate, Carcass Weight, Backfat Thickness, and lean Weight of Pigs, Journal of Animal Science, 77, 2352 - 2356.

Ujan, J. A., Zan, L. S., Shengjuan, W., Adoligbe, C., Wang, H. B. (2011). Meat tenderness and water holding capacity are associated with a 959 A G mutation in the MyoG gene of Chinese indigenous cattle, African Journal of Biotechnology, 10(29), 5654 - 5660.

Verner, J., Humpolicek, P., Knoll, A. (2007). Impact of MYOD family genes on pork traits in Large White and Landrace pigs. Journal of Animal Breeding and Genetics, 124(2), 81 - 85.

Weisz, F., Urban, T., Chalupova, P., Knoll, A. (2011). Association analysis of seven candidate genes with performance traits in Czech Large White pigs, Czech Journal of Animal Science, 56(8), 337 - 344.

Zhang, R. F., Chen, H., Lei, C. Z., Zhang, C. L., Lan, X. Y., Zhang, Y. D., Zhang, H. J., Bao, B., Niu, H., Wang, X. Z. (2007). Association between Polymorphisms of MSTN and MYF5 Genes and Growth Traits in Three Chinese Cattle Breeds, Asian-Australasian Journal of Animal Sciences, 20(12), 1798 - 1804. 